\title{
Prevalence of age-related macular degeneration in Japanese immigrants and their descendants living in Londrina (PR) - Brazil
}

\author{
Prevalência da degeneração macular relacionada à idade em japoneses e des- \\ cendentes em Londrina (PR) - Brasil
}

Ana Paula Miyagusko Taba Oguido ${ }^{1}$ Antonio Marcelo Barbante Casella ${ }^{2}$ Tiemi Matsuo ${ }^{3}$

Eduardo Henrique de Freitas Ramos Filho ${ }^{4}$ Rodrigo Berbel ${ }^{5}$

Ricardo Montanheiro Alcântara Silva ${ }^{6}$
Trabalho realizado na Universidade Estadual de Londrina - UEL - Londrina (PR) - Brasil.

Mestre em Medicina pela Universidade Estadual de Londrina - UEL - Londrina (PR) - Brasil.

${ }^{2}$ Professor Doutor, Chefe do Departamento de Oftalmologia da UEL - Londrina (PR) - Brasil.

Professora Doutora do Departamento de Matemática da UEL - Londrina (PR) - Brasil.

Graduando do curso de Medicina da UEL - Londrina (PR) - Brasil.

Graduando do curso de Medicina da UEL - Londrina (PR) - Brasil.

Médico oftalmologista do Hospital de Olhos de Londrina. Londrina (PR) - Brasil.

Correspondence to: Ana Paula Miyagusko Taba Oguido. Rua Mato Grosso, 1412 - Apto. 23 - Londrina (PR) CEP 86010-180

E-mail: aoguido@sercomtel.com.br

Recebido para publicação em 25.03.2007

Última versão recebida em 10.10.2007

Aprovação em 11.01.2008

Nota Editorial: Depois de concluída a análise do artigo sob sigilo editorial e com a anuência da Dra. Keila Miriam Monteiro de Carvalho sobre a divulgação de seu nome como revisora, agradecemos sua participação neste processo.

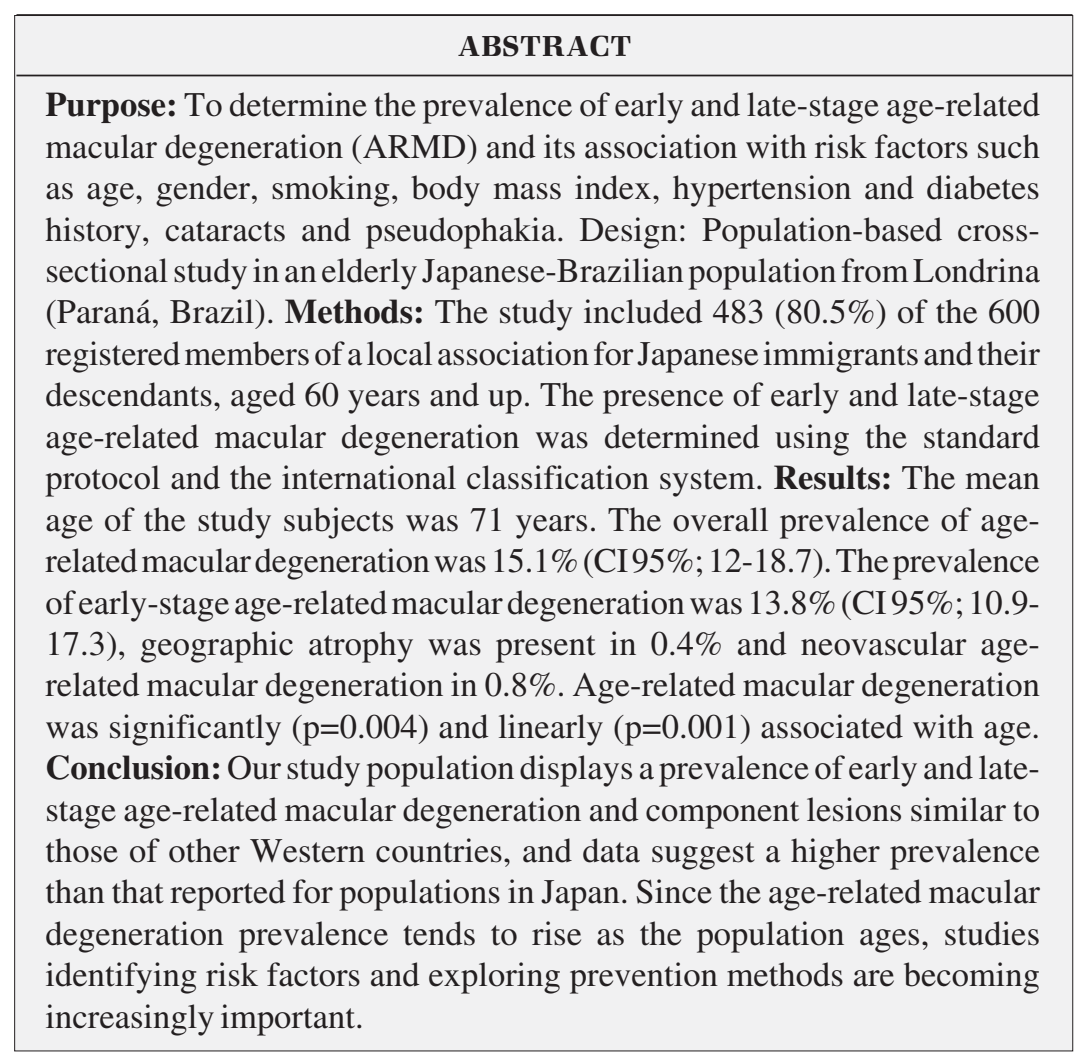

Keywords: Macular degeneration/epidemiology; Risk factors; Prevalence, Macula lutea.; Ethnic groups; Sex factors; Middle aged; Aged; Aged, 80 and over; Brazil/epidemiology

\section{INTRODUCTION}

Late stage of age-related macular degeneration (ARMD) is considered the main cause of legal blindness and irreversible loss of central sight in many developed countries. Considered a public health problem in some countries, the disease is responsible for approximately $50 \%$ of all cases of irreversible blindness ${ }^{(1)}$, affecting $20 \%$ to $35 \%$ of people over $75^{(2)}$.

Epidemiological estimates suggest that the prevalence of ARMD will increase all over the world as the elderly population becomes proportionally larger ${ }^{(3)}$. And an incidence rate increase of $5 \%$ to $27 \%$ over a 9 -year period was reported in the $\mathrm{USA}^{(4)}$. 
In Brazil an ARMD prevalence of $13.9 \%$ in an elderly population from the city of São Paulo was reported ${ }^{(5)}$. Previously considered a low-frequency disease in Japan, some authors ${ }^{(6)}$ reported an increase in the number of ARMD cases diagnosed in the last years, where the city of Hisayama showed a prevalence of $12,7 \% \%^{(7)}$.

However, the increase in prevalence cannot be fully explained by the growth of the elderly population. Environmental and behavioral factors also seem to have an impact on the incidence of the disease ${ }^{(8)}$. Environmental changes and the industrialization of society tend to interfere with lifestyle, customs and eating habits around the world. In fact, some authors tested this hypothesis in an isolated rural community in southern Italy and found a lower prevalence of the disease ${ }^{(9)}$.

Since the pathogenesis of ARMD remains unclear, no totally effective prevention therapy has been developed so far. Investigations have therefore been directed towards the identification of probable risk factors and their associations in order to develop prevention and intervention strategies capable of minimizing visual damage and improving prognosis, especially in patients with early-stage ARMD. Some risk factors, such as age, smoking, photo-toxicity and genetic predisposition, are more representative than others. Studies with twins ${ }^{(10)}$ have suggested the disease may be associated with certain genetic factors. Different forms of onset and degree of severity have been observed in genetically predisposed individuals and have been strongly associated with environmental factors.

An early diagnosis of ARMD via examination of the eye fundus and detection of manageable late-stage improves the prognosis, provides information on risk factors and facilitates clinical and preventive treatment. In some cases it can prevent the development of late forms of the disease responsible for important loss of sight and quality of life ${ }^{(11)}$.

The aim of this study was to identify the prevalence of early and late ARMD in a homogeneous population of Japanese descendants, aged over 60 years, residents of Londrina (PR) - Brazil. Moreover, the relationship between ARMD and risk factors, such as, age, gender, body mass index, cigarette smoking, hypertension and diabetes histories, cataract and pseudophakia was observed.

\section{METHODS}

The study was epidemiological and cross-sectional and was carried out in Londrina (a city in the state of Paraná, Brazil) between September 2002 and July 2003, evaluating the eye health condition of a statistically representative population of Japanese immigrants and their descendants aged 60 years and up. Individuals were eligible if born in Japan (immigrants) or in Brazil of Japanese-born parents (secondgeneration) and if at least 60 years old (or expected to turn 60 in the current year). Individuals with eye alterations preventing the detection of ARMD, such as lens, cornea and vitreous opacities, were excluded.
The study included registered members of all local associations for Japanese immigrants and their descendants, aged 60 years and up. After giving their informed written consent, the following eye examinations were performed: visual acuity (using the Snellen table), automated refraction (Topcon Corporation $^{\circledR}$, Tokyo, Japan), tonometry (Haag Streit ${ }^{\circledR}$, R-900, Swiss), lens grading at the slit lamp as defined by some authors ${ }^{(2)}$ and stereoscopic fundus examination using a slit lamp biomicroscope with a 78 D Superfield lens (Volk Optical Inc. ${ }^{\circledR}$, Mentor, Ohio, USA) $)^{(12)}$. The fundus examinations were performed after adequate pupil dilatation with 1 drop 1.0\% tropicamide (Mydriacyl ${ }^{\circledR}$, Alcon, Brazil) and 1 drop $10 \%$ phenylephrine (Fenilefrina $^{\circledR}$, Allergan, Brazil). Subjects showing signs of early or late-stage ARMD were referred to additional testing consisting of $50^{\circ}$ fundus photography performed with a Topcon TRC50 EX fundus camera (Topcon Corporation ${ }^{\circledR}$, Tokyo, Japan) coupled to a Sony HAD 3CCD color video camera (Sony Eletronics Inc ${ }^{\circledR}$, New York, NY) and an ophthalmic imaging system. Images were stored in a non-compressed JPG format.

Study subjects were classified according to the International ARM Epidemiological Study Group ${ }^{(13)}$ definition for early and late-stage ARMD. Early ARMD is defined as the presence of soft drusen $(>63 \mu \mathrm{m})$ or retinal pigment epithelium (RPE) abnormalities within the macula associated with drusen in the absence of late-stage ARMD in either eye. Two types of late-stage ARMD are recognized: a) neovascular or wet ARMD, defined by the presence of at least one of the following characteristics: RPE detachment in one of the eyes, subretinal or sub-RPE neovascular membranes; epiretinal, intraretinal, subretinal or sub-pigment epithelial scar or glial tissue; intra- or subretinal or sub-RPE hemorrhage, hard lipid exudates inside the macular area related to previous findings and photocoagulation scars from ARMD, and b) geographic atrophy (dry ARMD) of the RPE area with delimited hypopigmentation and depigmentation or apparent lack of RPE, where the choroidal vessels of the eye are visible in an area larger than $175 \mu \mathrm{m}$.

The age and gender-specific frequencies of each ARMD grade, as well as the diagnosed cases of early and late-stage ARMD were registered. The analysis was based on the most severe sign of the disease detected by stereoscopic biomicroscope eye examination. Information on hypertension and history of diabetes, smoking habits (subjects currently smoking or who have smoked for more than 6 months) and nonsmokers (subjects who never smoked) was recorded upon the first visit using a specific questionnaire. Body weight and height were measured in light clothing and barefoot to calculate the body mass index (BMI; weight $/$ height $^{2}$ ). Subjects were considered to be overweight when their BMI was above $25 \mathrm{~kg} / \mathrm{m}^{2}$. Patients with significant alterations on eye examination were informed about the problem and referred to further investigations and treatment.

The data were entered into a database and analyzed with the Epi Info software (version 6.04d, 2000), developed by the US Department of Health and Human Services/Public Health Service Center of Disease Control. 
A total of 950 eyes from 478 patients were included in the analysis, including the eye with ARMD with more advanced ARMD signs.

Using the eye as the experimental unit, descriptive measures of frequency, mean and standard deviation were obtained. The study variables (age, gender, history of hypertension and diabetes, smoking habits, body mass index, cataracts and pseudophakia) were analyzed with the chi-square test, the trend chi-square test, the Yates test and odds ratio calculation, with the confidence interval set at $95 \%$ and the level of significance at $5 \%(\mathrm{p}=0.05)$ for all tests.

The study was designed in accordance with the human research regulations and Resolution \#196/96 and was approved by the Research Ethics Committee at Londrina State University School Hospital (CEP official letter 022/02).

\section{RESULTS}

A total of 483 subjects (966 eyes), corresponding to $80.5 \%$ of the members of all local associations of Japanese immigrants and descendants, were enrolled in the study. Five people were excluded, three $(60 \%)$ of whom were females with an average age of 76.4 years, due to the impossibility of carrying out an eye fundus biomicroscopy for the diagnosis of ARMD in both eyes. Six people had only one eye analyzed.

Thus, only 478 people and 950 eyes were included in the analysis, including the eye that showed more advanced ARMD signs. The mean age was $71 \pm 6.7$ years $(60-92)$. Women and men accounted for $63.0 \%$ (301) and $37 \%$ (177) of the study population, respectively. The average body mass index was $23.5 \mathrm{~kg} / \mathrm{m}^{2}$, with a standard deviation of $3.7 \mathrm{~kg} / \mathrm{m}^{2}$. A history of hypertension was observed in 39.1\% (CI 95\%; 34.7-43.7), a history of diabetes in $17.8 \%$ (CI 95\%; 14.5-21.6), while smokers made up $16.1 \%$ (CI 95\%; 13.0-19.8) (Table 1). In the male population a greater number of smokers $(\mathrm{p}<0.001)$ and more extensive history of myocardial infarction ( $\mathrm{p}=0.029)$ were observed.

The total frequency of early and late-stage ARMD was $15.1 \%$ (CI 95\%; 12.0-18.7). The total ARMD frequency increased with age. Differences between age ranges were statistically significant $(\mathrm{p}=0.004)$ and displayed a linear trend $(\mathrm{p}=0.001)$.

\begin{tabular}{|c|c|c|c|c|}
\hline Variables & $\mathbf{n}$ & $\%$ & Cl & \\
\hline \multicolumn{5}{|c|}{ Hypertension } \\
\hline yes & 187 & $39.1 \%$ & $34.7 \%$ & $43.7 \%$ \\
\hline no & 291 & $60.9 \%$ & $56.3 \%$ & $65.3 \%$ \\
\hline \multicolumn{5}{|l|}{ Diabetes } \\
\hline yes & 85 & $17.8 \%$ & $14.5 \%$ & $21.6 \%$ \\
\hline no & 393 & $82.2 \%$ & $78.4 \%$ & $85.5 \%$ \\
\hline \multicolumn{5}{|c|}{ Smoking habits } \\
\hline yes & 77 & $16.1 \%$ & $13.0 \%$ & $19.8 \%$ \\
\hline no & 401 & $83.9 \%$ & $80.2 \%$ & $87.0 \%$ \\
\hline
\end{tabular}

Odds ratios were 2.11 (CI95\%; 1.20-3.71) and 3.18 (CI95\%; $1.44-$ 7.00) for the 70-79 and $>80$ year age ranges, respectively, when compared to the 60-69 year age range (Table 2). The frequency of early and late-stage ARMD was $14.6 \%$ (CI 95\%; 10.9-19.2) in females and $15.8 \%$ (CI 95\%; 10.8-22.0) in males. Gender differences were not statistically significant $(\mathrm{p}=0.171)$ (Table 3$)$.

The association between frequency of early and late-stage ARMD and age was statistically significant for both males $(\mathrm{p}=0.026)$ and females $(\mathrm{p}=0.034)$, and both genders displayed a linear trend $(\mathrm{p}=0.015$ and $\mathrm{p}=0.024$, respectively). Men and women over 80 were 3.33 (CI 95\%; 1.37-8.07) and 1.98 (CI 95\%; $0.78-5.06)$ times more likely to develop the disease, respectively, than subjects in the 60-69 year age range (Tables 4 and 5).

\begin{tabular}{|c|c|c|c|c|c|c|}
\hline \multirow{3}{*}{$\begin{array}{l}\text { Age } \\
\text { group }\end{array}$} & \multicolumn{4}{|c|}{ Sign of ARMD } & \multirow{3}{*}{$\begin{array}{c}\text { Total } \\
\mathbf{n}\end{array}$} & \multirow{3}{*}{$\begin{array}{l}\text { Odds ratio } \\
\text { Cl } 95 \%\end{array}$} \\
\hline & \multicolumn{2}{|c|}{ yes } & \multicolumn{2}{|c|}{ no } & & \\
\hline & $\mathbf{n}$ & $\%$ & $\mathbf{n}$ & $\%$ & & \\
\hline $60-69$ years & 22 & 9.7 & 204 & 90.3 & 226 & Reference \\
\hline 70 - 79 years & 38 & 18.5 & 167 & 81.5 & 205 & $2.11[1.20-3.71]$ \\
\hline above 80 years & 12 & 25.5 & 35 & 74.5 & 47 & $3.18[1.44-7.00]$ \\
\hline \multicolumn{7}{|c|}{$\chi^{2}($ Pearson $)=10.98 ; p=0.004 ; \chi^{2}$ of tendency $=10.92 ; 1 \mathrm{df}$ and $p=0.0010$} \\
\hline
\end{tabular}

Table 3. Frequencies of total ARMD (early and late) by gender in the Japanese-Brazilian population investigated in Londrina

\begin{tabular}{|c|c|c|c|c|c|c|c|}
\hline \multirow[t]{3}{*}{ Gender } & \multicolumn{6}{|c|}{ Sign of ARMD } & \multirow[t]{3}{*}{ Total } \\
\hline & \multicolumn{3}{|c|}{ yes } & \multicolumn{3}{|c|}{ no } & \\
\hline & $\bar{n}$ & $\%$ & Cl $95 \%$ & $\mathbf{n}$ & $\%$ & $\mathrm{Cl} 95 \%$ & \\
\hline Male & 28 & 15.8 & $10.8-22.0$ & 149 & 84.2 & $78.0-89.2$ & 177 \\
\hline Female & 44 & 14.6 & $10.9-19.2$ & 257 & 85.4 & $80.9-89.2$ & 301 \\
\hline \multicolumn{7}{|c|}{$\chi_{\text {Yates }}^{2}=1.87,1 \mathrm{df}$ and $p=0.171$} & \\
\hline
\end{tabular}

Table 4. Frequencies of total ARMD (early and late) in males by age group in the Japanese-Brazilian population investigated in Londrina

\begin{tabular}{|c|c|c|c|c|c|c|}
\hline \multirow{3}{*}{$\begin{array}{l}\text { Male age } \\
\text { group }\end{array}$} & \multicolumn{4}{|c|}{ Sign of ARMD } & \multirow{3}{*}{ Total } & \multirow{3}{*}{ Odds ratio } \\
\hline & \multicolumn{2}{|c|}{ yes } & \multicolumn{2}{|c|}{ no } & & \\
\hline & $\mathbf{n}$ & $\%$ & $\mathrm{n}$ & $\%$ & & \\
\hline $60-69$ years & 8 & 10.5 & 68 & 89.5 & 76 & Reference \\
\hline 70 - 79 years & 13 & 16.0 & 68 & 84.0 & 81 & $1.52[0.76-3.47]$ \\
\hline Above 80 years & 7 & 35.0 & 13 & 65.0 & 20 & $3.33[1.37-8.07]$ \\
\hline \multicolumn{7}{|c|}{$\chi^{2}($ Pearson $)=7.13,2$ df and $p=0.028 ; \chi^{2}$ (tendency $)=5.92,1 \mathrm{df}$ and $p=0.015$} \\
\hline
\end{tabular}

Table 5. Frequencies of total ARMD (early and late) in females by age groups in the Japanese-Brazilian population investigated in Londrina

\begin{tabular}{|c|c|c|c|c|c|c|}
\hline \multirow{3}{*}{$\begin{array}{l}\text { Female age } \\
\text { group }\end{array}$} & \multicolumn{4}{|c|}{ Sign of ARMD } & \multirow{3}{*}{ Total } & \multirow{3}{*}{ Odds ratio } \\
\hline & \multicolumn{2}{|c|}{ yes } & \multicolumn{2}{|c|}{ no } & & \\
\hline & $\mathrm{n}$ & $\%$ & $\mathbf{n}$ & $\%$ & & \\
\hline 60 - 69 years & 14 & 9.3 & 136 & 90.7 & 150 & Reference \\
\hline 70 a 79 years & 25 & 20.2 & 99 & 79.8 & 124 & $2.16[1.17-3.97]$ \\
\hline Above 80 yearss & 5 & 18.5 & 22 & 81.5 & 27 & $1.98[0.78-5.06]$ \\
\hline
\end{tabular}


In the early stage of the disease (drusen over $63 \mathrm{~mm}$ or drusen and RPE alterations) the frequency was $13.8 \%$ (CI 95\%; 10.9-17.3). In the late stage the frequency was $1.3 \%$ (CI 95\%; $0.5-2.9 \%)$, that is, $0.4 \%$ of the dry or atrophic type and $0.8 \%$ of the neovascular or exudative type.

The total frequency of early and late-stage ARMD was not associated with previous cataract surgery, body mass index above $25 \mathrm{~kg} / \mathrm{m}^{2}$, smoking habits or history of hypertension diabetes, or presence of cataract. One of the four patients with late-stage exudative ARMD, extensive hemorrhage and peripapilary disease was submitted to fluorescein angiography and indocyanine green video-angiography and diagnosed with polypoidal choroidal vasculopathy.

\section{DISCUSSION}

Results from this study stress the importance of ARMD in a Brazilian population of Japanese immigrants and their descendants. ARMD has been recognized as a complex and multifactorial disease. However, some factors, such as age and genetic predisposition, are more representative than others, and predisposed individuals may manifest the condition in the presence of appropriate environmental influences ${ }^{(8)}$. The importance of confirming the influence of such external factors lies in the fact that they are potentially changeable and may alter the course of the disease.

The prevalence of ARMD, as reported in a number of population studies in the literature, ranges from $4.5 \%$ to $41.6 \%$ for early-stage disease, and from $0.1 \%$ to $8.2 \%$ for late-stage disease. In the present study the corresponding findings were $13.8 \%$ (CI 95\%; 10.9-17.3) and $1.3 \%$ (CI 95\%; 0.5-2.9), respectively. The frequency observed was higher than that by some authors ${ }^{(2,7,9)}$ for both early and late-stage ARMD, and similar to others ${ }^{(5,14-16)}$

Our results may be compared to those of other population studies, provided that differences due to methodology are taken into account. In addition to the unique characteristics of each studied population, there are differences between the classification systems used, mainly in the classification of early-stage ARMD, whose definition has not been completely standardized. The definition of late-stage ARMD is more clear-cut, making comparisons more reliable. The methodology may also vary with regard to the diagnosis of ARMDrelated macular changes. The grading system proposed by some authors $^{(13)}$ and the Summary Grading Protocol ${ }^{(17)}$ which recommends stereoscopic photographs of eye fundus, have been used for diagnostic purposes; however, diagnosis may differ according to the used method. To avoid difficulties in visualizing fundoscopic lesions, the stereoscopic examination was performed with a macular magnifying lens ${ }^{(12)}$ (Volk Optical $\mathrm{Inc}^{\circledR}$, Mentor, Ohio, USA) coupled to a biomicroscope. Cases were documented for reassessment using eye fundus monoscopic digital photographs at $50^{\circ}$ (7). In addition, it should be pointed out that our study population was restricted to sub- jects aged 60 years and up, although the definition for ARMD is applicable to individuals from the age of $50 \mathrm{on}$.

Our study population may be compared to ethnically similar populations from Hisayama, Japan ${ }^{(7)}$. The observed differences included average age (65.2 vs. 71 years), number of female participants (59.9\% vs. 67\%), average body mass index $\left(23.2 \mathrm{~kg} / \mathrm{m}^{2}\right.$ vs. $\left.23.5 \mathrm{~kg} / \mathrm{m}^{2}\right)$, number of smokers $(18.1 \%$ vs. $16.1 \%)$ and frequency of diabetes (18.1\% vs. $17.8 \%)$.

Early and late-stage ARMD was more prevalent in the population from Londrina. The frequency of early-stage disease (for pigmentation alterations as well as for drusen) was $13.8 \%$ (Londrina) and $12.7 \%$ (Hisayama). The corresponding figures for late-stage disease were $1.3 \%$ (neovascular $0.8 \%$; atrophic $0.4 \%$ ) and $0.9 \%$ (neovascular $0.7 \%$; atrophic $0.2 \%$ ), respectively. Our findings for late-stage ARMD matched those of the in Caucasian populations ${ }^{(16)}$ in the USA (1.6\%). However, lower prevalences were found ${ }^{(14)}$ for the rural and urban populations of Victoria, Australia $(0.7 \%)$, and in the African-American populations $(0.2 \%)^{(18)}$. External factors may have contributed to the higher ARMD frequency found in our population, such as the subtropical climate, which may be associated with a higher susceptibility to damage from ultraviolet radiation and phototoxicity. Lower latitudes and greater exposure to solar radiation are associated with a higher frequency of cataracts ${ }^{(19)}$, these same environmental factors could be affecting the prevalence of $\mathrm{ARMD}^{(20)}$.

Another factor which may have maximized phototoxic effects upon the population from Londrina is the fact that most of the subjects are farmers and therefore more exposed to the sun than most other professionals. On the other hand, our study population has maintained certain traditional eating habits, such as diets rich in vitamins and minerals, which could hinder the development of $\mathrm{ARMD}^{(9)}$.

Pigmentation, a probable protecting factor, may account for the lower prevalence observed for black populations ${ }^{(18)}$ and the moderate prevalence found in Asian populations ${ }^{(21)}$. These factors need to be investigated and their role clarified by further studies.

Interestingly, Asian study populations display a relatively high frequency of exudative ARMD with RPE detachment ${ }^{(8,21)}$ and polypoidal choroidal vasculopathy is likewise a characteristic finding ${ }^{(22)}$. One of the four patients from our study who were affected by the neovascular form of the disease presented clinical characteristics typical of polypoidal choroidal vasculopathy, a finding which was confirmed by complementary tests.

Although the literature indicates that ARMD is more frequent among Japanese men than women, in our study the frequency was the same for the two genders $(p=0.171)$. However, the increase in risk estimates from the 60-69 year age to the $>80$ year age range was greater among men (OR: 3.33; CI $95 \%$; 1.37-8.07) than among women (OR: 1.98; CI 95\%; 0.875.06). This difference may be explained by an earlier, longer and more intense exposure to external and environmental risk factors. This seems to be supported by the greater number of 
smokers $(\mathrm{p}<0.001)$ and more extensive history of myocardial infarction $(\mathrm{p}=0.029)$ among the male population, in this study.

ARMD frequency increased with age $(p=0.004)$ as did the linear trend $(p=0.001)$, matching findings in the literature. In this study we suggest a possible association of ARMD with smoking habits, which should be considered an important risk factor due to its occurrence in most populations. However, these results are not conclusive due to the small number of cases and smokers and due to the lack of a subclassification of smokers according to consumption levels.

Though considered potential risk factors, arterial hypertension, history of diabetes and previous cataract surgery were not associated with ARMD in this study. However, the interpretation of risk factors was limited by the small sample of patients with advanced ARMD, making it impossible to study the early and late stages separately and to perform multivariate analyses. Multicenter studies with a greater number of cases would be more appropriate for the analysis of risk factors.

The present study shows some of the characteristic features of a population of Japanese immigrants and their descendants living in Londrina (Paraná, Brazil) and reinforces the importance of ARMD among the elderly. Future anatomical studies on the neovascular forms of ARMD and RPE detachment will help make these features even more evident.

The role of genetic and ethnic factors and the influence of environmental factors are important and require further research. Knowledge of environmental risk factors is very useful, since such factors are potentially changeable and allow for the establishment of prevention and orientation measures and treatment strategies for patients in the early stage of the disease or with a strong hereditary predisposition.

\section{CONCLUSION}

The prevalence of ARMD in Japanese immigrants and their descendants living in Brazil was comparable to that of other industrialized countries, though higher than the prevalence observed in studies with native Japanese populations. ARMD prevalence increased with age. Risk factors such as gender, body mass index, smoking habits, pseudophakia and history of hypertension and diabetes were not associated with ARMD in this study. Age was considered a distracting factor for the association between ARMD and cataracts. Our findings stress the importance of ARMD among the elderly and the need for further investigations.

\section{RESUMO}

Objetivo: Identificar a prevalência da degeneração macular relacionada à idade (DMRI) inicial e tardia na população de japoneses e descendentes e verificar a associação com os fatores de risco: idade, sexo, hábito de fumar, índice de massa corpórea, história de hipertensão e diabetes, catarata e pseu- dofacia. Métodos: Realizado um estudo transversal na população de japoneses e descendentes, acima de 60 anos, residentes na cidade de Londrina (PR) - Brasil. Quatrocentos e oitenta e três $(80,5 \%)$ das 600 pessoas registradas foram submetidas ao exame oftalmológico completo. A presença de degeneração macular relacionada à idade foi determinada seguindo um protocolo padrão e classificação internacional, no período de setembro de 2002 a julho de 2003. Resultados: A média de idade foi de 71 anos (60-92 anos). A prevalência da degeneração macular relacionada à idade foi de $15,1 \%$ (intervalo de confiança (I.C. 95\%: 12-18,7), sendo na fase inicial em 13,8\% (I.C. 95\%: 10,9-17,3) e na fase tardia (atrofia geográfica 0,4\% e membrana neovascular sub-retiniana $0,8 \%$ ) em 1,3\%. A degeneração macular relacionada à idade foi associada à idade $(p=0,004)$ e apresentou tendência linear $(p=0,001)$. Não foi observada associação entre a DMRI e os outros fatores de risco analisados. Conclusão: A prevalência da degeneração macular relacionada à idade neste estudo foi semelhante aos dos países do Ocidente, e é possível que ela seja maior do que a da população do Japão. Os dados comprovam a importância da degeneração macular relacionada à idade nessa população de japoneses e descendentes, e mais estudos são necessários para identificar os fatores de riscos e os métodos de prevenção.

Descritores: Degeneração macular/epidemiologia; Fatores de risco; Prevalência; Macula lútea; Grupos étnicos; Fatores sexuais; Meia-idade; Idoso; Idoso acima de 80 anos ou mais; Brasil/epidemiologia

\section{REFERENCES}

1. Foran S, Wang JJ, Mitchell P. Causes of visual impairment in two older population cross-sections: the Blue Mountains Eye Study. Ophthalmic Epidemiol. 2003;10(4):215-25.

2. Leibowitz HM, Krueger DE, Maunder LR, Milton RC, Kini MM, Kahn HA, et al. The Framingham Eye Study monography: An ophthalmological and epidemiological study of cataract, glaucoma, diabetic retinopathy, macular degeneration and visual acuity in a general population of 2361 adults, 19731975. Surv Ophthalmol. 1980;24(Suppl):335-610.

3. Bressler NM, Bressler SB, Congdon NG, Ferris FL $3^{\text {rd }}$, Friedman DS, Klein R, Lindblad AS, Milton RC, Seddon JM; Age-Related Eye Diseases Study Research Group. Potential public health impact of Age-Related Eye Disease Study results: AREDS report no 11. Arch Ophthalmol. 2003;121(11):1621-4. Comment in: Arch Ophthalmol. 2003;121(11):1634-6.

4. Lee PP, Feldman ZW, Ostermann J, Brown DS, Sloan FA. Longitudinal prevalence of major eye diseases. Arch Ophthalmol. 2003;121(9):1303-10.

5. Medina NH. Epidemiologia do envelhecimento: estudo oftalmológico populacional de idosos [tese]. São Paulo: Universidade Federal de São Paulo; 1997.

6. Yuzawa M, Tamakoshi A, Kawamura T, Ohno Y, Uyama M, Honda T. Report on the nationwide epidemiological survey of exudative age-related macular degeneration in Japan. Int Ophthalmol. 1997;21(1):1-3.

7. Oshima Y, Ishibashi T, Murata T, Tahara Y, KiyoharaY, Kubota T. Prevalence of age related maculopathy in a representative japanese population: the Hisayama study. Br J Ophthalmol. 2001;85(10):1153-7.

8. Bird AC. Age-Related Macular Disease: Aetiology and Clinical Management. J Comm Eye Health 1999;12(29):8-9.

9. Pagliarini S, Moramarco A, Wormald RP, Piguet B, Carresi C, BalaccoGabrieli C, et al. Age-related macular disease in rural southern Italy. Arch Ophthalmol. 1997;115(5):616-22.

10. Meyers SM, Greene T, Gutman FA. A twin study of age-related macular degeneration. Am J Ophthalmol. 1995;120(6):757-66. 
11. Bressler NM. Early detection and treatment of neovascular age-related macular degeneration. J Am Board Fam Pract. 2002;15(2):142-52.

12. Lim JI. Age-related macular degeneration. New York: Marcel Dekker; 2002. Chapter 12, Exsudative age-related macular; p.101-29.

13. Bird AC, Bressler NM, Bressler SB, Chisholm IH, Coscas G, Davis MD, et al. An International classification and grading system for age-related maculopathy and age-related macular degeneration. The International ARM Epidemiological Study Group. Surv. Ophthalmol. 1995;39(5):367-74.

14. McCarty CA, Mukesh BN, Fu CC, Mitchell P, Wang JJ, Taylor HR. Risk factors for age-related maculopathy: the Visual Impairment Project. Arch Ophthalmol. 2001;119(10):1455-62.

15. Gibson JM, Rosenthal AR, Lavery J. A study of the prevalence of eye disease in the elderly in an English community. Trans Ophthalmol Soc U K. 1985;104 (Pt 2):196-203.

16. Klein R, Klein BE, Linton KL. Prevalence of age-related maculopathy. The Beaver Dam Eye Study. Ophthalmology. 1992;99(6):933-43.

17. AREDS Summary Grading Protocol. Fundus phothograph reading center.
Appendix 15B. Wisconsin age-related maculopathy grading system [Internet] Madison: University of Wisconsin, Departament of Ophthalmology and Visual Science; 2000. Available from: http://eyephoto.ophth.wisc.edu/Research Areas/ AREDS/CHAPTER15B.html

18. Friedman DS, Katz J, Bressler NM, Rahmani B, Tielsch JM. Racial differences in the prevalence of age-related macular degeneration: the Baltimore Eye Survey. Ophthalmology. 1999;106(6):1049-55.

19. Sasaki H, Kawakami Y, Ono M, Jonasson F, Shui YB, Cheng HM, et al. Localization of cortical cataract in subjects of diverse races and latitude. Invest Ophthalmol Vis Sci. 2003;44(10):4210-4.

20. Young RW Sunlight and age-related eye disease. J Natl Med Assoc. 1992;84 (4):353-8.

21. Chang TS, Hay D, Courtright P. Age-related macular degeneration in Chinese-Canadians. Can J Ophthalmol. 1999;34(5):266-71.

22. Ciardella AP, Donsoff I, Huang SJ, Costa DL, Yannuzzi LA. Polypoidal choroidal vasculopathy. Surv Ophthalmol. 2004;49(1)25-37. Comment in: Surv Ophthalmol. 2004;49(6):620. 